\title{
STUDI APOLOGETIK KRISTEN TERHADAP KONSEP ANAK ALLAH YANG DITERAPKAN PADA PRIBADI YESUS KRISTUS
}

\author{
Esap Veri \\ Sekolah Tinggi Teologi Pelita Dunia Tangerang
}

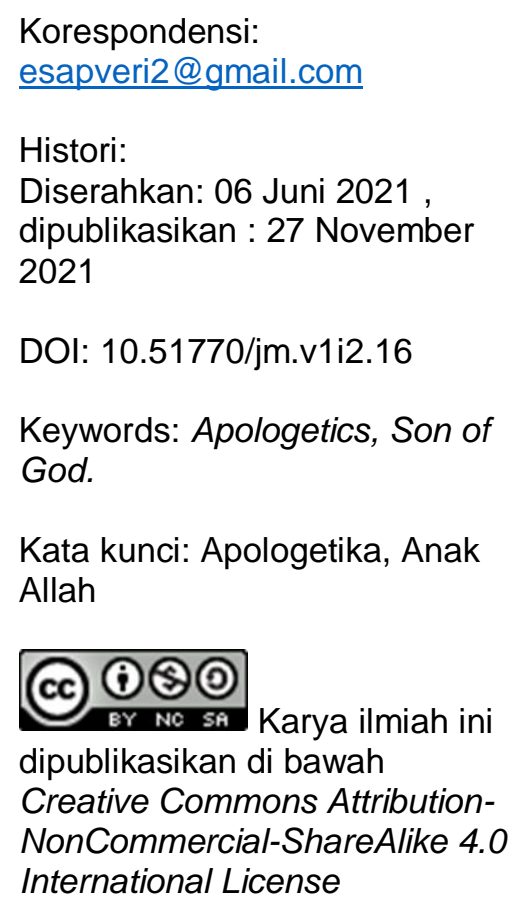

Abstract. In this satudy the author discusses the concept of the Son of God which is applied to the person of Jesus Christ in the study of Apologetics. This topic is controversial because it often distors theological understanding as if the Christian faith teaches that God has biological children and this creates a theological misunderstanding. This sometimes understood by non-Christian. Therefore, the author will use the study of literature in research in order to explain the phenomenon under study. This study shows that the concept of the Son of God is not a concept that means the biological son of God. But the concept of the son of God is a concept that has meaning: first, Jesus is equal to God the Father. Second, Jesus Christ is the unique Son of God as well as having a personal relationship with the Father, so that it is the Son who reveals the entire existence of the Father. who has uniquely revealed the exixtence of the Father.

Abstrak. Dalam penelitian ini penulis membahas konsep "Anak Allah" yang diterapkan pada pribadi Yesus Kristus dalam kajian apologetika. Topik ini menjadi kontroversi karena sering distorsi pemahaman teologis yang seolah-olah iman Kristen mengajarkan bahwa Allah itu beranak dalam makna biologis dan hal menimbulkan kesalahpahaman teologis. Hal inilah yang kadang dipahami oleh kalangan non-Kristen. Oleh karena itu, penulis akan menggunakan kajian pustaka dalam penelitian ini dalam rangka menjelaskan fenomena yang diteliti. Penelitian ini menunjukan hasil bahwa konsep Anak Allah bukan sebuah konsep yang bermana anak biologis Allah. Ttetapi konsep Anak Allah merupakan konsep yang memiliki makna: pertama, Yesus setara dengan Allah Bapa sejak kekekalan dan kedua, Yesus Kristus adalah Anak Allah yang unik sekaligus memiliki hubungan personalitas dengan Bapa, sehingga Anak yang menyatakan seluruh eksistensi Bapa.

\section{PENDAHULUAN}

Iman Kristen adalah iman yang berpusat pada pribadi Yesus

Kristus (kristosentris) sekaligus sentral utama dalam pemberitaan Gereja. 
Karena itu, Gereja masa kini dituntut agar terus menyaksikan siapakah pribadi Yesus Kristus itu dalam iman Kristen. Termasuk topik Kristologi harus dipahami secara utuh dan benar, karena Dialah Pribadi yang sepenuhnya llahi dan juga manusiawi. Keilahian merupakan dimensi iman Kristen yang berbicara mengenai sifat-sifat Ilahi atau gelar-gelar Ilahi sebelum inkarnasi-Nya. Keilahian menegaskan bahwa Yesus Kristus adalah Pribadi Allah Tritunggal yang setara dengan Allah Bapa. Sebaliknya, kemanusiaan Kristus merupakan natur tambahan pada saat inkarnasi-Nya.

Dalam perjalanan iman Kristen, telah diwarnai dengan adanya perdebatan. Berkaitan dengan sentral iman Kristen yaitu pribadi Yesus Kristus, seringkali menjadi isu yang diperbincangkan, diperdebatkan atau pun diragukan keotentikan pribadi-Nya. Dua natur dalam Pribadi Yesus Kristus kadang menjadi polemik dalam iman Kristen dan non-Kristen. Itulah sebabnya, Arjuna L Batu membenarkan bahwa Pribadi Yesus seringkali diperdebatkan entah dalam kekristenan maupun di non-Kristen (Arjuna L. Batu, 2013)

Berkaitan dengan tema "Anak Allah" maka tentunya perlu kajian yang mendalam karena tema ini kadangkala menjadi tantangan iman Kristen. Seringkali tema ini disalahpahami oleh kebanyakan non-Kristen, dan tentu masih banyak orang Kristen yang belum memahami konsep "Anak Allah". Stenly R. Paparang mengatakan, sebutan Anak Allah dalam 
pandangan Islam mengurangi kesempurnaan Allah sehingga mereka memaknai makna tersebut Allah bernak secara biologis sehingga menimbulkan persepsi yang salah (Stenly R. Paparang, 2019).

Selain itu, Lukas Kuswanto menuliskan ada pemahaman yang berpendapat bahwa ungkapan Anak Allah berarti, la beranak dan mempunyai seorang istri (Lukas Kuswanto, 2016). Jadi tampaknya orang Kristen harus memberi klarifikasi, agar pemahaman semacam ini tidak serta merta membangun argumentasi yang tidak sesuai keyakinan umat Kristen.

Muncul juga bahasa, "kok Tuhan beranak?" "Siapa bidan-Nya?" Tentu istilah "beranak" tidak selalu bermakna biologis. Memang dalam Alkitab, ada istilah "Anak" yang bermakna biologis. Misalnya kisah Abraham yang diuji kepercaayannya oleh Allah. Di sana Allah memerintahkan Abraham untuk mengambil anaknya yang tunggal yakni, Isai (Kejadian 22:2). Tentu "anak" dalam kisah ini harus dimaknai sebagai anak biologis Abraham dengan Sarah. Istilah "Anak Allah" merupakan istilah yang telah disalah pahami oleh kebanyakan orang, apalagi nonKristen. Paparang mengatakan, mayoritas Muslim memahami bahwa Allah Kristen beranak secara biologis sehingga dianggap tidak masuk akal (Paparang, 2019). Itulah sebabnya mereka tidak menerima Yesus Kristus disebut sebagai "Anak Allah" karena logika mereka tidak memahami makna yang termaktub dalam Alkitab. Menurut Kevin T. Rey, Qur'an 
menolak status Yesus sebagai Anak Allah dan inilah perbedaan fundamental teologi Kristen dengan Islam (Kevin T. Rey 2013).

Selain itu, ada ungkapan "anak" dalam makna kiasan. Misalnya anak kunci atau anak tangga. Frasa ini menimbulkan pertanyaan, siapakah yang melahirkan "anak kunci" tersebut? Dapatkah kunci melahirkan secara fisik? Tentu frasa "anak kunci" tidak bermakna secara fisik dan kunci tentu tidak memiliki istri. Oleh karena itu tidak semua "anak" harus dipahami sebagai hasil hubungan biologis. Demikian juga dengan istilah "Anak Allah" yang diterapkan pada Pribadi Yesus Kristus.

Karena itu preposisi mengenai konsep Anak Allah tidalaklah bergantung pada asumsi teologi yang dipaksakan tanpa ada bukti yang kredibel. Maka yang utama untuk memahaminya tentu bergantung pada konsep Alkitab sebagai satu-satunya standar ajaran iman Kristen yang bisa mengevaluasi kebenaran ajaran tentang konsep "Anak Allah".

Hal inilah yang telah menjadi beban bagi penulis untuk mencoba mengkaji makna yang terkandung dalam istilah "Anak Allah" sehingga pada akhirnya orang Kristen bisa mengkomunikasikan imannya kepada orang yang keliru memahaminya. Sehingga pertanyaannya: apakah makna sesungguhnya Yesus disebut sebagai Anak Allah? Apakah istilah "Anak Allah" mutlak dipahami dalam konteks biologis? Seperti apa pandangan Alkitab mengenai konsep "Anak Allah" yang diterapkan pada Pribadi Yesus Kristus? Inilah yang akan dikaji dalam tulisan ini. Tujuan 
penelitian ini ialah untuk memberi pembelaan dengan dasar argumentasi teologis biblis agar orang percaya memahami secara utuh mengenai makna konsep "Anak Allah" dalam Alkitab.

\section{METODE PENELITIAN}

Dalam penelitian ini penulis menggunakan metode kualitatif deskriptif yang tentunya bertumpu pada literatur sebagai sumber primer dalam mengumpulkan data untuk dikelola guna menjabarkan sebuah fenomena yang sedang dikaji. Sebagaimana yang diungkapkan oleh Adi Putra mengatakan, kajian kualitatif bertumpu pada kajian literatur melalui sumber-sumber primer seperti buku, artikel jurnal, ensiklopedia dan majalah (Adi Putra, 2020).

Dengan demikian, metode kualitatif deskriptif dapat menolong penulis untuk mendeskripsikan makna yang sesungguhnya tentang konsep "Anak Allah" dan bisa menolong para pembaca untuk memahami secara benar perihal konsep "Anak Allah" agar bisa mengkomunikasikan imannya secara bertanggung jawab.

\section{HASIL PENELITIAN}

Topik Kristologi merupakan topik penting untuk ditelaah secara mendalam. Isu tentang "Anak Allah" yang kadang menjadi polemik melahirkan pemahaman bahwa Allah beranak secara biologis. Alkitab sebagai otoritas orang percaya tidak mengajarkan hal demikian. Justru 
sebaliknya, Alkitab memberi pemahaman yang cukup jelas dan kebenarannya memuat ajaran yang sangat Alkitabiah tentang doktrin Kristologi.

Jadi sejauh ini, argumentasi-argumentasi yang dibangun dengan tujuan membungkam iman Kristen perihal konsep "Anak Allah" dapat ditolak dengan dasar otoritas Alkitab. Data-data Alkitab mulai dari Perjanjian Lama sampai kepada Perjanjian Baru tidak mencatat bahwa Allah memiliki seorang anak dalam konteks biologis.

Justru informasi yang diperoleh ketika menyelidiki Alkitab dalam rangka untuk membangun pemahaman teologis perihal konsep "Anak Allah" yang khusus diterapkan pada Pribadi Yesus Kristus yaitu: pertama, menyatakan kesetaraan Ilahi antara Pribadi Bapa dengan Pribadi Anak dan menjelaskan ajaran praeksistensi sang Logos. Kedua, untuk menjelaskan relasi personal antara Bapa dengan Anak yang khusus dan unik.

\section{PEMBAHASAN}

Pembahasan ini mencakup argumentasi teologis biblis sebagai dasar untuk pembelaan perihal makna "Anak Allah".

\section{Konsep Perjanjian Lama tentang "Anak Allah"}

Konsep Anak Allah pertama kali muncul dalam tradisi Perjanjian Lama seperti dalam Kejadian 6:2 "maka anak-anak Allah melihat, bahwa 
anak-anak perempuan manusia itu cantik....;" Ayub 1:6 "Pada suatu hari datanglah anak-anak Allah menghadap TUHAN....;" Mazmur 82: 6 "Aku sendiri telah berfirman: "Kamu adalah allah, dan anak-anak Yang Mahatinggi kamu sekalian."

Kemudian beberbagai penggunaan istilah anak Allah dalam Perjanjian Lama seperti: (a) bagi bangsa Israel, Kel. 4:22; Yer. 31: 9; Hos. 11: 1; (b) para pemimpin Israel, terutama para raja di bawah keturunan Daud, II Samuel 7:14; Maz. 89:27; (c) para malaikat, Ayb. 1:6; 2:1; 38:7; Maz. 29:1: 89:6; dan (d) orang-orang yang sangat setia dan taat secara umum, Kej. 6:2; Maz. 73:15; Ams. 14:26" (Berkhof, 2008). Selanjutnya Berkhof berkomentar: "di antara bangsa Israel nama itu memperoleh arti teokratis yang penting" (Berkhof, 2008). Artinya bahwa istilah "Anak Allah" memberi gagasan bahwa Allah sebagai pemimpin tertinggi bangsa Israel. Sedangkan menurut David Iman Santoso, umat Israel juga disebut sebagai anak-anak Allah (Hosea 11:1), demikian pula dengan raja dan imam (2 Ssamuel 7:14; Maleakhi 1:6) ( David Iman Santoso, 2009).

Dari uraian di atas tampak jelas bahwa pengunaan "Anak Allah" dalam Perjanjian Lama digunakan untuk manusia pada umumnya. Namun dalam ayat-ayat lain di Perjanjian Lama, ada yang berbicara nubuatan tentang sosok Mesias dari keturunan raja Daud. Misalnya Yesaya 9:6 tentang anak yang memiliki gelar-gelar keilahian yang akan duduk di atas tahta Daud. 
Dalam Mazmur 2:7, di sini muncul satu kali istilah "Anak-Ku Engkau Kuperanakan hari ini." Mazmur ini sering disebut para ahli sebagai Mazmur Mesianik. Mazmur Mesianik merupakan Masmur yang sedang menggambarkan sosok Mesias dari keturunan raja Daud. Siapakah yang dimaksud "Anak-Ku" dalam teks tersebut? Dalam Perjanjian Baru, Mazmur ini sering dikutip untuk menjelaskan Pribadi Yesus. Dalam Ibrani 1:5 penulis Ibrani sedang membandingkan Yesus Kristus yang lebih unggul dari para malaikat. Dalam Ibrani 5:4-5, penulis Ibrani kembali mengutip Mazmur 2:7, di mana dalam konteks ini panulis lbrani sedang membandingkan keimaman Yesus Kristus dengan keimaman Harun. Dalam teks yang lain di Perjanjian Baru, Mazmur 2:7 dikutip oleh Lukas dalam Kisah Para Rasul 13:32-33 yang dalam konteks ini Paulus sedang berbicara mengenai kebangkitan Yesus Kristus. Jadi apabila memperhatikan kacamata Perjanjian Baru, maka sesungguhnya yang dimaksud penulis Mazmur 2:7 adalah Yesus Kristus. Itulah sebabnya, Matthew Henry benar ketika dia menafsirkan, Dia adalah Anak Allah, bukan anak angkat, melainkan Anak yang dilahirkan-Nya, Anak Tunggal Bapa (Yohanes $1 ; 14)$. Itulah sebabnya Bapa mengakui-Nya dan tanpa dipertanyakan lagi, la benar-benar bersyarat dan dipercaya, dan Anak itu sekodrat dengan Bapa, mempunyai kepenuhan ke-Allahan. Hikmat, kuasa, kekudusan di dalam diri-Nya (Matthew Henry, 2011). 
Tampaknya nas-nas dalam Perjanjian Lama menggabarkan "anakanak Allah" kepada keakraban antara orang-orang yang setia kepada Allah, umat Israel, nabi, imam dan raja dengan Allah. Dalam konteks umat Israel istilah "Anak Allah" lebih menekankan teokrasi Allah. Sedangkan dalam konteks keturunan Daud lebih menekankan kepada sosok "Mesianik" yang akan duduk di atas tahta Daud. Dalam konteks Mesianik, pembaca harus melihat progresif pewahyuan Allah, bahwa sosok Mesias yang dimaksud ialah Yesus Kristus sebagai Anak Daud.

\section{Konsep Injil Kanonik tentang “Anak Allah”}

Pada bagian ini penulis hanya membatasi membahas konsep "Anak Allah” dalam empat injil yaitu Injil Matius, Injil Markus, Injil Lukas, dan Injil Yohanes.

\section{a. Injil Matius}

Matius mencatat Yesus sebagai Anak dalam kisah la dibaptis (3:17), transfigurasi (17:5) dan pada kematian-Nya (27:54) (David Iman Santoso, 2009). Pada peristiwa pembaptisan suara Bapa terdengar bahwa Yesus adalah Anak yang dikasihi Bapa, hal ini terkonfirmasi dalam urapan Roh Kudus yang turun dalam wujud burung merpati. Setelah Yesus dideklarasikan sebagai Anak Allah dalam kisah pembaptisan, maka Injil Matius mencatat dalam pasal 4 tentang duel antara Yesus Kristus dengan Iblis. Ingat, bahwa Adam pertama gagal dalam pencobaan di taman Eden 
ketika iblis datang dan memutar balikan fakta Firman Tuhan supaya Adam tidak percaya Firman Tuhan yang telah didengarnya. Dalam kasus yang sama, ketika Yesus dideklarasikan sebagai Anak Allah oleh Bapa dalam rangka misi mesianik-Nya, Iblis datang untuk mencobai Yesus supaya meragukan identias tersebut. Namun, dalam duel tersebut, Yesus tampil sebagai pemenang yang akan mengalahkah secara total kerajaan Iblis di atas kayu salib.

Dalam Matius 11:27 Yesus sedang menjelaskan kekuasaan yang dimiliki Bapa telah diserahkan kepada Anak, karena antara Anak dan Bapa terjalin relasi personal sejak kekekalan. Dan hanya Anak sebagai gambar Allah yang layak menyingkapkan Bapa secara sempurna.

Murid-murid menyembah Dia sambil berkata, "Sesungguhnya Engkau adalah Anak Allah" (14:33). Pernyataan di atas hendak menegaskan sebuah kebenaran bahwa Yesus benar-benar Pribadi yang datang dari kekekalan sebagai Mesias. Kata "sesungguhnya" dari kata alethos: truly, menunjuk pada pengakuan kebenaran yang pasti, yang berarti bahwa mereka menyembah Yesus dengan mengakui Yesus adalah Anak Allah"(Santoso, 2009). Murid-murid mengakui Yesus sebagai Anak Allah karena setelah melewati badai besar mereka sadar bahwa, hanya Allah yang sanggup menolong dan meneduhkan badai tersebut. Dan Dialah Tuan atas hukum alam. Dalam Mat. 16:16 Petrus secara tegas mengakui Yesus Kristus sebagai Anak Allah. Dalam konteks ini, Yesus 
sedang mengajukan sebuah pertanyaan penting tentang siapakah Yesus Kristus? Beragam jawaban yang didengar oleh Yesus. Pada akhirnya, la meminta jawaban Petrus. Petrus memberi jawaban, sebagai sebuah pengakuan akan identitas penting, yaitu Mesias, Anak Allah. Matius mengonfirmasikan bahwa pernyataan ini bukan pernyataan dari manusia semata, melainkan penyingkapan dari Allah.

Pada peristiwa kematian Yesus Kristus kepala pasukan Romawi tampak ada di sana dan tiba-tiba dilingkupi ketakutan karena telah terjadi perstiwa-peristiwa yang luar biasa. Namun dalam peristiwa ini, justru yang sebelumnya menyiksa Yesus Kristus, berubah percaya dengan pengakuan, "Sungguh, la ini Anak Allah." Ini adalah ungkapan iman yang juga pernah diucapkan oleh Petrus dalam Matius 16:16. Dan hal ini sejalan dengan tema utama Injil Matius, yaitu memperkenalkan Yesus sebagai raja Mesias.

Dari sekian pemaparan di atas, penulis menyimpulkan bahwa pada dasarnya konsep Anak Allah dalam Injil Matius membangun pemahaman relasi personal antar Bapa dan Anak bukan secara biologis. Hal ini muncul dari pengakuan Allah Bapa, Iblis, dan Petrus. Selain itu, maksud yang lain yang hendak ditegaskan bahwa ungkapan Anak Allah dalam Matius seperti kisah kepala pasukan dan murid-murid pada saat badai menghantam mereka. Ungkapan "Anak Allah" merupakan ungkapan lebih 
kepada indentias Ilahi hal ini terkonfirmasi karena situasi yang mereka lihat secara langsung dan interfensi Allah untuk mengubah hati mereka.

\section{b. Injil Markus}

Dalam Markus, ia pagi-pagi memperkenalkan Yesus Kristus dengan menyebutnya sebagai "Anak Allah" yang akan disampaikan dalam tulisannya. Hal senada dengan pendapat Welly Pandensolang yang mengatakan, Markus memulai dengan memperkenalkan Krisus sebagai Anak Allah (Markus 1:1) (Pandensolang, 2009). Santoso mempertegas dengan berkata, Markus memulai dengan memperkenal Yesus sebagai Anak Allah (1:1) dan mengakhiri dengan pengakuan kepala pasukan Romawi yang mengakui Yesus sebagai Anak Allah (15:39) (Santoso, 2012). Itulah sebabnya bagi Markus, Injilnya di mulai memperkenalkan Kristus sebagai Anak Allah yang datang menjadi hamba yang menderita dalam rangka menjalankan misi-Nya.

Dalam kisah pembaptisan seperti yang dicatat oleh Matius dan Lukas, Markus juga menyebut Yesus sebagai Anak yang dikasihi, sehingga diperkenankan oleh Bapa-Nya. Artinya istilah Anak di sini merupakan hubungan personal antara Bapa dengan Anak. Pada waktu Yesus ke daerah Gerasa, la bertemu dengan orang yang kerasukan setan dan sebelumnya belum mengenal siapa Yesus. Namun Markus melaporkan bahwa orang itu berteriak, "Apa urusan-Mu dengan aku, hai 
Yesus, Anak Allah Yang Mahatinggi?" (Markus 5:7). Tampaknya roh jahat yang mengakui Yesus sebagai Anak Allah. Dalam Markus pasal 9 Markus mencatat kisah Yesus yang dipermuliakan di atas gunung, di sana ada konfirmasi dari Bapa di sorga mengenai Anak yang dikasihi. Markus melaporkan agar apa yang telah dinyatakan mengenai status Yesus sebagai Anak Allah, supaya tidak diceritakan kepada orang lain. Hal ini untuk menghindari kesalah pahaman di kalangan orang Yahudi.

Tampaknya Markus menggunakan istilah "Anak Allah" sebagai identitas Ilahi. Hal itu telah diselidiki di atas seperti laporan pertama Markus 1:1, pengakuan roh jahat, konfirmasi di atas gunung, serta perngakuan kepala pasukan yang juga dicatat dalam Matius.

\section{c. Injil Lukas}

Lukas pun tidak ketinggalan untuk menyajikan konsep Anak Allah sebagaimana dalam kisah pemberitaan malaikat sebelum kelahiran Yesus Kristus, ia mengatakan bahwa Yesus akan disebut Anak Allah (Lukas 1:35) (David Iman Santoso, 2012). Artinya bahwa konsep Anak Allah adalah tema yang penting juga bagi Lukas untuk menyajikan sosok-Nya yang Ilahi. Pandensolang memberi komentarnya, "Lukas pun tentunya sangat memahami seruan malaikat mengenai gelar Yesus sebagai Anak Allah, sehingga ia terdorong untuk menulis kebenaran itu dalam Injilnya (Luk. 1:35)" (Pandensolang, 2009). Jadi ketika Lukas menulis kisah 
kelahiran Yesus Kristus, malaikat yang memberitakannya justru menggunakan gelar "Anak Allah" untuk memberi pemahaman bahwa: (1) Yesus Kristus telah berpraeksistensi, (2) Yesus Kristus sosok yang ilahi (3) sehakekat dengan Allah Bapa dan Roh Kudus (4) kelahiran-Nya bukan interfensi manusia atau pertemuan sel sperma dan sel telur. Itulah sebabnya Egber Brink benar ketika menyebut, ungkapan "dikandung dari Roh Kudus" sebagai asal usul Yesus dari Allah sendiri dan menyatakan kesetaraan wujud dengan Allah (Brink, 2016).

Dalam kasus yang lain yaitu pada saat Yesus dihadapkan di hadapan Mahkamah Agama, dalam interogasi di hadapan sidang Mahkamah Agama, la ditanyai, kata mereka semua: "Kalau begitu, Engkau ini Anak Allah?" jawab Yesus: "Kamu sendiri mengatakan, bahwa Akulah Anak Allah" (Luk. 22:70). Kalis Stevanus menyampaikan pendapatnya, pada saat Yesus menyebut diri-Nya Anak Allah maka la mengklaim diri-Nya sama dengan Allah. Dan hal itu dimengerti oleh orangYahudi sebagai pernyataan kesetaraan dengan Allah (Stevanus, 2016). Melalui kasus ini dapat disimpulkan bahwa dalam sidang di hadapan Mahkamah Agama, Yesus secara langsung mengakui identitasnya yang otentik dan ilahi bahwa Anak Allah itu setara dengan Allah Bapa.

Dalam peristiwa kematia-Nya di kayu salib, kepala pasukan melihat proses kamatian Yesus. Lukas mencatat dalam pasal 23:47 bahwa kepala 
pasukan Romawi tersebut memuji Allah oleh karena ia melihat bahwa sesungguhnya Yesus Kristus tidak layak untuk mendapat hukuman mati, karena Dia orang benar. Meskipun dalam laporan Matius dan Markus menyebut "Anak Allah" dalam kisah kematian-Nya, namun pesan yang disampaikan sama. Bahwa seandainya Yesus Kristus bukan Allah, maka la tidak layak menjadi Juruselamat dunia, karena kebenaran ada padaNya.

Berdasarkan laporan Lukas di atas, penulis menyimpulkan bahwa makna yang ditegaskan sehubungan dengan tema "Anak Allah" ialah hubungan yang menyatakan identitas Yesus Kristus yang ilahi. Hal ini tampak dari perkataan malaikat kepada Maria mengenai Anak Allah yang kudus, pengakuan roh jahat tentang Anak Allah, serta pengakuan Yesus sendiri di hadapan Mahkamah Agama. Bahkan ditegaskan oleh kepala prajurit.

\section{d. Injil Yohanes}

Yohanes pasal 1 telah menyebut Yesus Kristus sebagai "Anak Allah" sebanyak tiga kali. Yohanes 1:13, Yohanes menyebutkan bahwa Yesus adalah Anak Tunggal Allah yang menyatakan siapa Bapa. Hal ini menarik, karena pasal 1:1, Firman atau Anak Allah telah berpraeksistensi bersama dengan Bapa. Itulah sebabnya Yesus sebagai Anak Allah yang layak menyatakan sepenuhnya Allah dalam diri-Nya. Yohanes pembaptis 
pun mengakui bahwa Yesus adalah Anak Allah (ayat 34). Di pasal 3, Yohanes menyebutkan Yesus sebagai Anak Allah di empat ayat yaitu 16, 17, 18, 36. Di pasal 10, di sini orang Yahudi menuduh Yesus menghujat Allah karena menyebut diri-Nya sebagai Anak Allah. Maria pun mengakui Yesus sebagai Anak Allah pada pasal 11:4. Dan memang tujuan penulisan Injil Yohanes agar semua orang percaya bahwa Yesus adalah Mesias, Anak Allah (20:31).

Konsep Anak Allah dalam injil Yohanes menggunakan istilah "monogenes" sebanyak 4 kali dalam menggambarkan Yesus sebagai Anak Tunggal Allah. Kata "monogenes" berasal dari kata "monos" yang artinya "tunggal" atau "sendirian", dan "genos" yang artinya "jenis" atau "keturunan" (Santoso, 2014). Artinya, istilah "monogenes" memberi gagasan teologis bahwa Yesus Kristus satu-satunya anak yang unik, spesial daripada yang lain. Serta asal usul-Nya yang datang dari Bapa. Maka Yohanes mengatakan, tidak seorang pun yang pernah melihat Allah, tetapi Anak Tunggal Allah, yang dipangkuan Bapa, Dialah yang menyatakan-Nya (Yohanes 1:18).

Sebagaimana penggunaan istilah "Anak Allah" dalam keempat injil dapat ditarik kesimpulan bahwa keempat Injil tersebut sama-sama menenakankan keilahian Yesus Kristus serta menegaskan bahwa Yesus Kristus telah ada sejak kekekalan bukan diciptakan dan bukan anak dalam makna biologis. Maka dari itu, perspektif Perjanjian Baru seperti dalam injil 
kanonik melaporkan istilah Anak Allah lebih spesifik merujuk kepada seorang Mesias yaitu Yesus Kristus. Maka sebutan Anak Allah merupakan hubungan personalitas antara Bapa dengan Anak serta sebutan untuk identias Ilahi bagi Yesus Kristus.

\section{Apologetika Kristen terhadap Konsep Anak Allah}

Konsep Anak Allah sebagaimana dikatakan di atas merupakan tema yang telah didistorsi maknanya. Maka diperlukan argumentasi sebagai pembelaan iman (baca berapologetika) yang merupakan tanggung jawab iman Kristen. Rasul Petrus menuliskan 1 Ptr. 3:15, "Tetapi kuduskanlah Kristus di dalam hatimu sebagai Tuhan! Dan siap sedialah pada segala waktu untuk memberi pertanggungan jawab kepada tiap-tiap orang yang meminta pertanggungan jawab dari kamu tentang pengharapan yang ada padamu, tetapi haruslah dengan lemah lembut dan hormat."

Pembelaan iman bertujuan agar orang Kristen bisa mengkomunikasikan imannya secara baik dan penuh kasih, untuk memuliakan Allah. Itulah sebabnya Paparang mengatakan, Tuhan tidak menjadikan kita sebagai orang percaya yang pendiam, tidak tegas, serta bermasa bodoh yang memendam kebenaran, tidak peduli kondisi yang sedang terjadi, melainkan sebagai orang yang aktif menyatakan kebenaran" (Paparang, 2016). Artinya asas-asas kebanaran iman Kristen 
yang selama ini disalah mengerti, orang Kristen perlu memberikan penjelasan yang kredibel secara tegas tanpa rasa malu dan takut. Dan inilah yang perlu diluruskan sehingga tidak menimbulkan penafsiran yang keliru.

Ada beberapa poin yang perlu dipertahankan kebenarannya perihal konsep "Anak Allah".

Pertama, Allah tidak pernah melahirkan secara fisik. Tidak ada data-data Alkitab yang mengajarkan hal demikian. Alkitab mengajarkan Allah adalah Roh. Maka perlu dipahami bahwa hanya daging yang memiliki hasrat seksual. Hanya manusia yang memiliki hasrta seksual. Dan karena itulah Alkitab tidak pernah mengajarkan Allah melakukan hubungan biologis. Dan Allah tidak pernah disebut dalam Alkitab memiliki anak secara biologis.

Kedua, konsep "Anak Allah" bermakna pada hubungan personal antara Bapa dengan Yesus (makna analogi). Yesus Kristus yang adalah Firman memiliki relasi yang spesial dengan Allah Bapa hal ini terbukti ketika Yesus Kristus berkata: "Aku dan Bapa adalah satu" (Yohanes 10:30). Dalam ayat tersebut orang Yahudi marah karena Yesus menyatakan bahwa la memiliki relasi yang khusus dengan Allah. Millard J. Erickson mengomentari gelar tersebut dengan berkata: “.....,Yesus menggunakan dengan arti yang baru untuk menjelaskan pribadi-Nya yang unik serta hubungan-Nya dengan Allah. Gelar ini menandakan bahwa 
Yesus memiliki hubungan dengan Allah Bapa yang berbeda dengan hubungan yang dimiliki oleh orang lain" (Erickson, 2015).

Itulah sebabnya, Henry C. Thiesen menyebut sebagai hubungan yang indah antara seorang Anak Allah dengan Bapa-Nya di sorga dalam konsep Perjanjian Baru (Thiesen, 2015).

Ketiga, konsep "Anak Allah" lebih mengacu kepada identitas Ilahi Yesus Kristus dan kesetaraan dengan Bapa (makna ontologi). Yohanes 5:18 memberi kejelasan bahwa konsep "Anak Allah" sangat jelas mengacu pada identitas Yesus Kristus sebagai Allah karena Yesus menyebut Allah sebagai Bapa-Nya. Hal ini terkonfirmasi oleh orang Yahudi tersinggung ketika Yesus Kristus menggunakan gelar tersebut sebagai kesamaan yang setara dengan Allah. Paul Enns mengomentari insiden dalam ayat tersebut dengan berkata, orang Yahudi tentu faham akan ungkapan atau klaim Yesus sebagai Anak Allah sebagai klaim menjadikan diri setara dengan Allah (Enns, 2019). Jadi bagi orang Yahudi klaim tentang Anak Allah sudah pasti merujuk kepada kesetaraan dengan Allah Bapa. Dan bagi orang Yahudi ketika seorang manusia biasa mengungkapkan istilah Anak Allah untuk diterapkan pada dirinya maka itu sebuah penghujatan besar bagi Allah.

Larry W. Hutardo menjelaskan beberapa insiden antara Yesus dengan orang Yahudi perihal ketika Yesus menggunakan gelar "Anak Allah" untuk menyamakan diri-Nya dengan Allah Bapa seperti berikut: 
"Dalam Injil Yohanes, tuduhan orang Yahudi bahwa Yesus menghujat muncul dalam percakapan dan perdebatan antara Yesus dan orang-orang Yahudi dan itu terkait dengan pernyataan Yesus bahwa Dia adalah "Anak Allah" (Yohanes 10:36). Kemudian para pemimpin Yahudi menafsirkan bahwa Yesus membuat pernyataan yang menghina Allah "Engkau menghujat Allah dan karena Engkau, sekalipun hanya seorang manusia saja, menyamakan diri-Mu dengan Allah," (ayat 33). Dalam perikop 19:7 orang-orang Yahudi menyatakan Yesus bersalah melakukan pelanggaran besar terhadap Hukum Taurat sebab menganggap diri-Nya "Anak Allah" (Larry W. Hurtardo, n.d.)

Hal yang sama, ketika Yesus menggunakan gelar "Anak Allah" untuk menyatakan dirin-Nya setara dengan Allah maka orang Yahudi ingin melempari dengan batu. Karena karena ketika Yesus menyebut, "Aku dan Bapa adalah satu" (10:33). Orang Yahudi merasa la hanya manusia biasa lalu menjadikan diri-Nya Allah. Dan tentu mereka mengerti ungkapan Yesus tersebut, sehingga mereka marah" (Boyd, 2001).

Charles C. Ryrie menjelaskan bahwa orang-orang saat itu menganggap Yesus tidak layak mangatkan "Akulah Anak Allah" (Yohanes 10:36) karena ungkapan ini sebuah ungkapan yang menyatakan diri setara dengan Allah (Ryrie, 1991). Jadi tiga argument tokoh di atas menunjukan relaita betapa mengertinya orang Yahudi dengan istilah "Anak Allah" yaitu kesetaraan dengan Allah Bapa. Maka hal tersebut 
menimbulkan reaksi yang bernuansa negatif dari kalangan orang Yahudi kendatipun mereka menolak dan tidak percaya pada Yesus Kristus sebagai Allah sejati. Itulah sebabnya, Rirye mengatakan: "Petunjuk "Anak Allah" merupakan klaim yang kuat dan jelas untuk Keallahan yang penuh (Ryrie, 1991). Jadi jelas penggunaan "Anak Allah" justru hendak menyatakan keilahian Yesus Kristus.

Keempat, konsep "Anak Allah" merupkan konsep Kristologi yang mengajarkan atau membktikan praeksistensi Anak. Istilah yang spesifik tentang istilah "Anak Allah" yaitu penggunaan gelar "Anak Tunggal". Misalkan Yohanes 1:14, 18; 3:16. Gelar tersebut dalam original teks disebutkan dengan kata "monogenes" yang secara hurufiah bermakna anak yang satu-satunya. Maka istilah tersebut sesungguhnya membawa pada pengertian bahwa Yesus Kristus adalah Firman yang bersama-sama dengan Allah, dan sang Firman itu sendirilah yang telah menyatakan siapa sesungguhnya Allah itu melalui inkarnasi. Jadi gelar "Anak Tunggal" menyatakan Yesus Kristus yang ilahi bukan dalam pengertian hasil bubungan fisik atau biologis.

Adi Putra memberi penjelasan yang baik perihal "monogenes (Anak Tunggal)" dalam Injil Yohanes dengan mengatakan, makna monogenes dalam injil Yohanes hendak menekankan hubungan spesial dan unik antara Anak dengan Bapa, bukan metafisik, kata ini menggambarkan keunikan hubungan Yesus dan Bapa bahwa sejatinya Yesus sama 
dengan Bapa. Sekaligus menegaskan tentang praeksistensi dan keilahian Yesus Kristus (Putra, 2021).

Perihal arti "Anak Tunggal", Peter Wongso menjelaskan demikian, arti Anak Tunggal ialah satu-satunya yang mewarisi sifat ilahi Allah Bapa dan pekerjaan Bapa, wahyu Bapa, dan Dia satu-satunya yang menyatakan sifat Bapa kehidupan, kemuliaan, kekasaan, dan lain-lain. Sehingga hubungan-Nya dengan Bapa bukan hubungan biologis (Wongso, 1993). Maka tentunya di sini ada sebuah titik pemahaman penting bahwa Yesus Kristus ketika mendapat gelar Anak Allah, sejatinya hendak menegaskan kualitas ilahi bukan biologis manusiawi. Hal itu ditegaskan oleh Peter Kraff dan Ronald K. Tacelli dengan mengatakan, Yesus menyebut diri-Nya Anak Allah karena berarti la memiliki sifat yang sama dengan Allah (Kraft dan Tacelli, 2006).

Itulah sebabnya, Stephen Tong menegaskan gagasan "dilahirkan" dengan mengatakan istilah dilahirkan menunjukkan bahwa Dia bukan diciptakan; Dia bukan ciptaan. Sebutan Anak Tunggal bagi Yesus mengindikasikan bahwa Dia satu-satunya yang dilahirkan, bukan diciptakan (Tong, 2015). Maka ketika Yesus disebut Anak Allah, la menyatakan asal usulnya yang telah bersama-sama dengan Bapa. R.C Sproul menegaskan, Anak Allah secara kekal berasal dari Allah Bapa, Dia bukanlah ciptaan, tetapi Pribadi kedua dari Tritunggal (Sproul, 2020). 
Kelima, konsep "Anak Allah" justru menegaskan bahwa Yesus Kristus yang layak menjadi Juruselamat. Preposisi, "Anak Allah adalah anak secara biologis" bukan sebuah konsep yang Alkitabiah. Karena Alkitab justru menjelaskan makna yang jauh lebih dalam dan teologis.

Keenam, konsep "Anak Allah" juga bisa digunakan untuk menyatakan relasi antara orang percaya dengan Allah. Artinya orang percaya disebut Anak Allah dalam makna adopsi. Karena pada waktu belum percaya kepada Yesus Kristus, manusia adalah seteru Allah. Namun Allah mengangkat statusnya menjadi anak-anak-Nya. Dalam Galatia 4:5 frasa "diterima menjadi anak" diterjemahkan dalam KJV "adoption of sons." Hal yang sama dalam Roma 8:14 melalui frasa, "tetapi kamu telah menerima Roh yang menjadikan kamu anak Allah". Dalam versi KJV, frasa ini diterjemahkan "but you have received the Spirit of adoption." Maka di sini terjadi perubahan status saat percaya (Yohanes 1:12).

Dengan demikian dapat katakan bahwa uraian-uraian di atas tidak memberi satu data pun bahwa Allah beranak dalam konteks biologis, justru ayat-ayat di atas meluruskan pandangan-pandangan yang mengklaim bahwa Allah itu beranak secara biologis atau seks. Jadi Alkitab sebagai fondasi iman Kristen tidak membenarkan pandangan bahwa Allah beranak secara jasmani. 


\section{KESIMPULAN}

Iman Kristen adalah iman yang tidak pernah mengajarkan Allah beranak secara metafisik atau bilogis. Jadi konsep "Anak Allah" tidaklah bermakna secara metafisik. Maka konsep "Anak Allah" yang diterapkan pada Pribadi Yesus Kristus memiliki makna khusus dan mendalam yaitu:

Pertama, secara ontologi, konsep "Anak Allah" memiliki makna bahwa Yesus Kristus sehakekat dengan Allah Bapa. Artinya konsep tersebut hendak menyajikan sosok Yesus Kristus yang Ilahi bahwa la adalah Allah telah berpraeksistensi sebelum berinkarnasi menjadi manusia sejati.

Kedua, Secara analogi, konsep "Anak Allah" hendak menjelaskan bahwa Yesus Kristus memiliki relasi yang khusus dengan Allah Bapa. Artinya Yesus Kristus adalah Anak Tunggal Allah yang unik, Dialah Anak Allah yang menyatakan Allah yang sebenarnya di dalam gambar atau wujud Anak Allah karena sejak semula sang Anak telah bersama-sama dengan Bapa dalam kekekalan.

Dalam konteks orang-orang percaya kepada Yesus Kristus, istilah "Anak Allah" digunakan untuk menyatakan status rohani. Artinya pada saat orang percaya kepada Yesus Kristus, ia diadopsi menjadi anak-anak untuk pewaris kerajaan Allah. 


\section{DAFTAR PUSTAKA}

Batu, Arjuna. L. 2013. Yesus Kristus Tuhan dan Manusia. Surabaya: Pustaka Kristen.

Berkhof, Louis. 2008. Teologi Sistenatika 3. Surabaya: Momentum.

Boyd, Frank. M. 2001. Kristus Kehidupan dan Pelayanan-Nya. Malang: Gandum Mas.

Brink, Egbert. 2016. Semata-Mata Oleh Firman. Jakarta: Yayasan Komunikasi Bina Kasih.

Enns, Paul. 2019. The Moody Handbook Of Theology 1. Malang: Literatur SAAT.

Erickson, Millard. J. 2015. Teologi Kristen Volume 2. Malang: Gandum Mas.

Hurtardo, Larry. W. n.d. Sesungguhnya Yesus Adalah Allah. Malang:

Henry, Matthew. 2011. Tafsiran Matthew Henry Kitab Mazmur 1-50. Surabaya: Momentum.

Kuswanto, Lukas. 2016. 21 Bukti Yesus Adalah Tuhan. Yogyakarta: ANDI Offset.

Kreef, Peter., dan Ronald K. Telly. (2006). Pedoman Apologetik Kristen 1. Bandung: Kalam Hidup.

Pandensolang, Welly. 2009. Kristologi Kristen. Jakarta: YAI Press.

Paparang, Stenly. R. 2016. Apologetika Diskursus dan Vindikasi Iman Kristen. Medan: Prodi Teologi STT Medan Sumatera Utara.

. 2019. Yesus Kristus Anak Allah: Sebuah Tinjauan Filsafat Logika. Luwuk: Pustaka Star's Lub.

Putra, Adi. 2020. Kajian Biblika Ta Stigma Tou lesou dalam Galatia 6:17. SUNDERMAN: Jurnal Ilmiah Teologi, Pendidikan, Sains, Humaniora, Dan Kebudayaan.

Putra, Adi. 2021. PRA-EKSISTENSI YESUS. PRA-EKSISTENSI YESUS Berdasarkan Bukti-Bukti Dari Injil Yohanes, (May). 
Ryrie, Charles. C. 1991. Teologi Dasar 1. Yogyakarta: ANDI Offset.

Rey, Kevin. T. 2013. Konsep Yesus Anak Allah: Suatu Apologetika Terhadap Pandangan "Allah Tidak Beranak dan Tidak Diperanak". Jurnal Antusias.

Santoso, David. I. 2009. Teologi Matius. Malang: Literatur SAAT. . 2012. Teologi Markus. Malang: Literatur SAAT. . 2014. Theologi Yohanes. Malang: Literatur SAAT.

Sproul, R. C. 2020. Kebenaran-Kebenaran Dasar Iman Kristen. Malang.

Stevanus, Kalis. 2016. Apologetika: Benarkah Yesus Itu Tuhan? Yogyakarta: ANDI Offset.

Thiesen, Henry. C. 2015. Teologi Sistematika. Malang: Gandum Mas.

Tong, Stephen. 2015. Allah Tritunggal. Surabaya: Momentum.

Wongso, Peter. 1993. Dasar Iman Kepercayaan Kristen. Malang: Literatur SAAT. 